Research Paper

\title{
ANALYZING STAKEHOLDER INVOLVEMENT IN URBAN DO- MESTIC WATER SUPPLY SYSTEM - CASE STUDY IN CENTRAL HIGHLAND OF VIETNAM
}

\author{
Nguyen Tuan Anh ${ }^{1}$, Nguyen Ninh Hai ${ }^{1}$, Tran Thi Thao Trang ${ }^{1}$, \\ Bach Quang Dung' ${ }^{2}$, Nguyen Minh $\mathrm{Ky}^{{ }^{*}}$
}

\section{ARTICLE HISTORY}

Received: August 12, 2019 Accepted: October 08, 2019

Publish on: October 25, 2019

\section{ABSTRACT}

Ensuring adequate and safe water supply is a top priority in human life, especially cities or residential areas. Accessibility and safety in water supply services requires good operation in the components of domestic water supply systems including water sources, water treatment plants, and distribution network systems. This means that the cooperation and coordination of stakeholders (SH) should be good to help maintain the stable system. Therefore, it is necessary to analyse stakeholder involvement, indicating their responsibilities and roles in maintaining the system. The most appropriate level of involvement is presented to clasify the roles of each stakeholder when operating the system. Analyzing the stakeholders are based on two attributes of interest-power matrix, and then classifiying three most appropriate level of involvement including co-working, co-thinking, co-knowing.

Keywords: Water supply, Stakeholder analysis Co-working, Co-thinking, Co-knowing, Interest-power matrix

\section{Introduction}

Waterborne disease remains one of the major health concerns in the world. Diarrhoeal dis- eases, which are largely derived from contaminated water and inadequate sanitation (WHO, 2005). Deaths of 502000 can be atributed to unsafe and insufficient drinking-water and 297000 are due to inadequate handwashing, of these deaths, $88 \%$ occur in Africa and South- East Asia (WHO, 2014).

In some cities of Vietnam, the quality of water sometimes does not meet the requirements of national standards QCVN 01:2009/BYT for drinking water and QCVN 02:2009/BYT for domestic water when water comes to consumers (MONRE, 2014). The causes were identified as poor pipelines, the high rate of leakage, polluting water sources and inadequate water quantity for meeting the demands of locals. To improve that status, water safety plan is first introduced by World Health Organization (WHO, 2005), and manual has recently published on implementing a WSP (World Health Organization and International Water Association, 2009). The aim of a WSP is to ensure that a water supply system consistently produces safe water that is acceptable to consumers. Major stakeholders that could affect or be affected by decisions or activities of the drinking-water supplier should be encouraged to coordinate their planning and manage-

$\triangle$ Nguyen Minh Ky

Corresponding author: nmky@hcmuaf.edu.vn

${ }^{1}$ Nong Lam University of Ho Chi Minh City - Gia Lai campus, Vietnam

${ }^{2}$ Viet Nam Meteorological and Hydrometeorological Administration, Ha Noi, Vietnam 
ment activities where appropriate (WHO, 2011). The WSP approach requires water utilities to work with other stakeholders to make them aware of their responsibilities and the impact that their actions have on the utility's ability to supply safe drinking-water. The WSP approach promotes dialogue, education and collaborative action to remove or minimize risks (Bartram et al., 2009). Moreover, stakeholder engagement is not separate from other management processes (Conallin et al., 2017).

A domestic water supply system will be included the processes from the water source to the users. These components are water source, water treatment plant and distribution network system, so there are many organizations and agencies involved in the system that are responsible for each part of the system (Bartram et al., 2005). Therefore, the management of the system must have the coordination of stakeholders to ensure that the system is managed and operated well (WHO, 2005).

Therefore, a stakeholder analysis plays an important role in managing water supply systems (Wang et al., 2013). First, this will help to understand the responsibilities and obligations of the parties at each stage of the process (from water sources to users) to ensure that the parties fulfill their responsibilities (Reed et al., 2009; Yawson and Greiman, 2014). Moreover, this helps to avoid overlapping and difficulties in management. Second, understanding the responsibilities will facilitate stakeholders to coordinate periodically or solving problems arising in the management process.

In 1984 Freeman wrote the seminal work Strategic Management: A Stakeholder is "any group or individual who can affect or is affected by the achievement of the organization's objectives" (Freeman, 1984). Stakeholder analysis is an approach, a tool or set of tools for generating knowledge about actors - individuals and organizations - so as to understand their behaviour, intentions, interrelations and interests; and for assessing the influence and resources they bring to bear on decision-making or implementation processes (Varvasovszky, 2000). Stakeholder analysis allows managers to identify the interests of different groups and find ways of harnessing the support of those in favour or the activity, while managing the risks posed by stakeholders who are against it (DFID, 2003). The stakeholders in drinking water supply system are identified (Wang et al., 2013) including water companies, Governement, consumers, polluting companies, communities, experts and professional institutions, media and NGOs.

This study focus on analysing the most appropriate level of involvement of stakeholders in the urban water supply system in Pleiku city, Gialai province - A case study in central highland of Vietnam. In which, there are main stakeholders related to three components of water supply system such as Water Company, Department of Natural Resource and Environment, Department of Transport Gialai, Users, Government (Anh et al., 2019).

\section{Methodology}

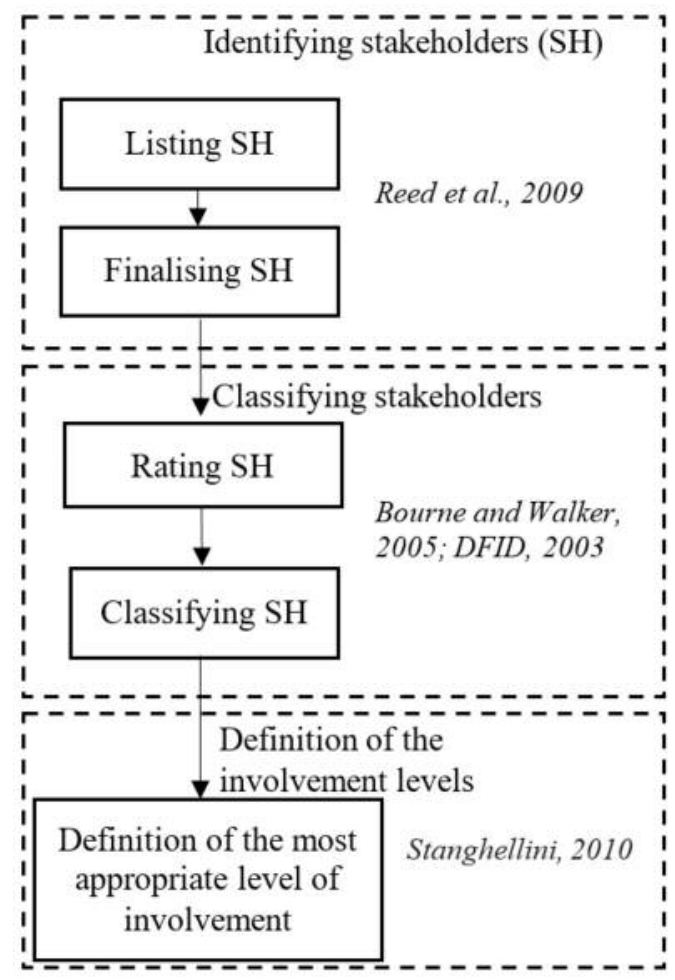

Fig. 1. Research framework 
The analysis of stakeholders in the domestic water supply system will be conducted in three steps: Identifying stakeholders, Clasifying stakeholders, Definiton of the appropriate level of involvement of each stakeholder.

\subsection{Identification of stakeholders}

Stakeholders can be defined as actors who have an interest in the issue under consideration, who are affected by the issue, or who - because of their position - have or could have an active or passive influence on the decision-making and implementation processes. They can include individuals, organizations, different individuals within an organization, and networks of individuals and/or organizations (Suchman, 1995).

The widespread use of the term "stakeholder" was defined by Freeman as "any group or individual who can effect or is affected by the achievement of the firm's objective" (Freeman, 1984). Stakeholders in drinking water supply systems can be regarded as actors who have an interest in drinking water supply systems, who are affected by drinking water supply safety, or who have or could have an active or passive influence on decision-making and implementation processes.

Stakeholder identification needs to be done in a process with focus groups, expert opinion, semi-structured interviews, snowball sampling, or a combination of these methods (Reed et al., 2009). Based on an initial review of secondary sources (e.g., published and unpublished documents, policy statements, internal regulations of organization, etc.), potential stakeholders in this study were identified, and then conduct interviews (semi-structured interviews) representing stakeholders to conduct a review of the stakeholder list, and adding or removing any stakeholders. A final list of stakeholders is used to classify stakeholders in the next step.

After collecting all data (reports, documents, laws), a list of stakeholders is fully listed. Fol- lowing the semi-structured interview method with staff, leaders involved in the domestic water supply system including water sources, water treatment plants and distribution system (leadership, installation personnel, maintenance and maintenance) to consider deciding whether to add or remove stakeholders. After interviewing the last table, the media and experts in water supply field were added to the task, the Gialai Department of Natural Resources and Environment (DONRE) has added the function to control water pollution.

\subsection{Classification of stakeholders}

Likert scaling may be described in the following manner. A set of items, if possible composed of approximately an equal number of favorable and unfavorable statements concerning the attitude object, is given to a group of subjects. They are asked to respond to each statement in terms of their own degree of agreement or disagreement. The specific responses to the items are combined so that individuals with the most favorable attitudes will have the highest scores while individuals with the least favorable attitudes will have the lowest scores (Likert, 1932). The interest-influence matrix is an approach for conducting a stakeholder analysis which is usually adopted as a management tool in project design (Romanelli et al., 2011; Caputo, 2013). Bourne and Walker (2005) have developed this concept in an index of interest-impact. Variables are the level of interest/likelihood of impact and the level of influence/power level, placed on a scale of 1 to 5 . The ranking of interest and influence/power can be divided into 5 levels (low, low-medium, medium, mediumhigh, high). Apart from, the handbook of Department for International Development guides how to score each stakeholder, use a five-point scale where level 1 is very little importance or influence, and level 5 is very great importance or influence (DFID, 2003). This study uses a 
scale of 1 to 5 corresponding to the levels of interest - influence/power components. This research are based on the levels of ranking scores, the questionnaire of representatives of stakeholders are proposed to collect. After collecting the scores from surveys of 50 stakeholders $(\mathrm{n}=$ 50), datta are analysed by SPSS software 13.0.

Based on the stakeholder power-interest matrix, the stakeholders were subsequently divided into four basic groups: context setters/keep satisfied - stakeholder group with high potential; key players - stakeholder group with a high level of interest and power; crowd/minimal effort stakeholder group with low level of interest and power; subjects/keep informed - stakeholder group with a high level of interest and low level of power (Driscoll and Starik, 2004; Wang et al., 2013; Yang et al., 2018).

\subsection{Definition of the level of involvement of each stakeholder}

After classifying stakeholders, it is important to decide how to involve the stakeholders. This is possible using the classification, which is very simple, clear and exhaustive: co-operating/coworking, co-thinking, co-knowing (Aggens et al., 1995; Stanghellini and Collentine, 2008).

Stanghellini (2010) identifies three different degrees of stakeholder involvement: co-working, co-thinking, and co-knowing. Co-working indicates stakeholders who actually participate in and contribute actively to the drinking water supply system. Co-thinking means stakeholders who have an input with respect to content and are sources of expert knowledge. Co-knowing means that stakeholders do not play an active role in the process but should be kept informed. After analyzing the mean score for power and interest atributes, scores of both attributes, which are higher than 3 , should be classified as definitive stakeholders, while those with one attribute of higher than 3 are expectant stakeholders, while both attributes with scores of lower 3 , are latent stakeholders. Corresponding to these 3 levels are co-working, co-thinking, and coknowing stakeholders (Stanghellini, 2010).

\section{Results and discussions}

\subsection{Identification of stakeholders in urban} water supply system

Among stakeholders Gialai water supply company plays the most important role because it is responsible for treating and supplying water to users safely and adequately. The government is the one who makes the relevant policies and laws, so it plays an important role and affects the operation of the system (Wang et al., 2013). The protection of water resources is the responsibility of DONRE, but the surrounding community is a contributor to the protection of water resources. This is very important because a stable source of water with quality and reserves will help the Plant operate stably, which helps provide water to users safely and adequately. The Department of Construction is primarily responsible for the operations, general management of the pipeline network, and the water supply company will be responsible for installation, operation, maintenance and maintenance. These are important stakeholders in the system because it helps to safely transport water from the treatment plant to its users and not to be polluted. Control of water quality in the pipeline network is the responsibility of the Department of Health/Preventive Medicine Center for sampling, quality control and information disclosure (Anh et al., 2019). 
Nguyen Tuan Anh et al./ Vietnam Journal of Hydrometeorology, 2019 (2-1): 56-65

Table 1. Interaction between stakeholders and urban water supply system

\begin{tabular}{|c|c|c|c|c|}
\hline No. & Stakeholders & Role & Effects on the system & $\begin{array}{c}\text { The system affects } \\
\text { stakeholders }\end{array}$ \\
\hline 1 & $\begin{array}{l}\text { Gialai Water Supply } \\
\text { Joint Stock Company }\end{array}$ & $\begin{array}{l}\text { Producing and } \\
\text { delivering clean water }\end{array}$ & $\begin{array}{l}\text { Direct impact on the quality } \\
\text { of treated water and adequate } \\
\text { distribution of water }\end{array}$ & $\begin{array}{l}\text { Can be affected by } \\
\text { operating costs of } \\
\text { systems, policies that put } \\
\text { pressure on operations }\end{array}$ \\
\hline 2 & Users & $\begin{array}{l}\text { Purchasing and using } \\
\text { clean water }\end{array}$ & $\begin{array}{l}\text { Demand may affect the } \\
\text { operation of the piping system }\end{array}$ & $\begin{array}{l}\text { Affect daily needs of life } \\
\text { and can affect health }\end{array}$ \\
\hline 3 & $\begin{array}{l}\text { State } \\
\text { agencies/organisations } \\
\text { Gialai hydraulic joint } \\
\text { stock company } \\
\text { Department of Health/ } \\
\text { Gialai center for } \\
\text { preventive medicine } \\
\text { Environmental Police } \\
\text { Department } \\
\text { Gialai electricity } \\
\text { company }\end{array}$ & $\begin{array}{l}\text { Supporting } \quad \text { and } \\
\text { monitoring operation } \\
\text { of system }\end{array}$ & $\begin{array}{l}\text { Monitoring water quality } \\
\text { Supervising the pollution of } \\
\text { water sources } \\
\text { Providing ancillary services } \\
\text { (energy) }\end{array}$ & No significant impact \\
\hline 4 & Governments & $\begin{array}{ll}\text { Creating } & \text { the } \\
\text { mechanism } & \text { and } \\
\text { introducing } & \\
\text { regulations, laws } & \end{array}$ & $\begin{array}{l}\text { May impact the treatment } \\
\text { process (through regulations } \\
\text { and regulations) } \\
\text { Impact on pipeline network } \\
\text { planning, water source } \\
\text { protection } \\
\text { Other preferential policies } \\
\text { and subsidies }\end{array}$ & $\begin{array}{l}\text { Direct impact by social } \\
\text { equity and development } \\
\text { goals }\end{array}$ \\
\hline 5 & $\begin{array}{l}\text { Communities (living } \\
\text { around the lake and } \\
\text { pipeline system) }\end{array}$ & $\begin{array}{l}\text { Protecting the } \\
\text { integrity of water } \\
\text { supply system }\end{array}$ & $\begin{array}{l}\text { May cause water pollution } \\
\text { May cause a number of } \\
\text { incidents (broken pipes ...) }\end{array}$ & No significant impact \\
\hline 6 & $\begin{array}{l}\text { Key agencies } \\
\text { Department of Natural } \\
\text { Resource } \\
\text { Environment and } \\
\text { Department of Transport } \\
\text { Gialai }\end{array}$ & $\begin{array}{l}\text { Managing the main } \\
\text { components of water } \\
\text { supply system }\end{array}$ & $\begin{array}{l}\text { Water resource management } \\
\text { and exploitation } \\
\text { Pipeline } \\
\text { management }\end{array}$ & $\begin{array}{l}\text { Impacting on } \\
\text { development goals and } \\
\text { ensuring social security }\end{array}$ \\
\hline 7 & Media & $\begin{array}{l}\text { Informing and } \\
\text { announcing news } \\
\text { related to the system }\end{array}$ & $\begin{array}{l}\text { May affect public opinion } \\
\text { through issues, complaints } \\
\text { and incidents related to the } \\
\text { system }\end{array}$ & No significant impact \\
\hline 8 & Experts and institutions & $\begin{array}{l}\text { Sharing and studying } \\
\text { good practice }\end{array}$ & $\begin{array}{lr}\text { Indirect impact } & \text { through } \\
\text { guidance } & \text { and } \\
\text { recommendations } & \\
\end{array}$ & No significant impact \\
\hline
\end{tabular}

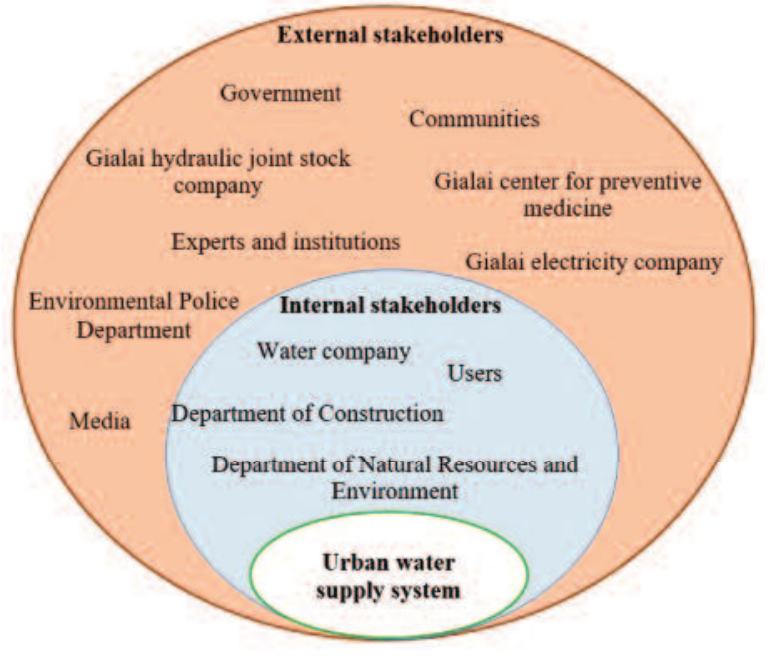

Internal stakeholders can be defined as those who are formally connected with the project (e.g. owners, customers and employees), whereas external stakeholders are those affected by the project in some way (Gibson, 2000). Therefore, internal stakeholders can be defined as those whose actively participate in three components including water resource, water plants, distribution system. In addition, external stakeholders are any those whose support the system. Identifying internal and external stakeholders are consulted experts.

Fig. 2. Internal and external stakeholders in urban water supply system 


\subsection{Classification of stakaholders}

Table 2. Results of interest score analysis

\begin{tabular}{ccccccc}
\hline Interest of SH & N & Range & Minimum & Maximum & Mean & $\begin{array}{c}\text { Std. } \\
\text { Deviation }\end{array}$ \\
\hline I1 & 50 & 4.00 & 1.00 & 5.00 & 4.1200 & 0.79898 \\
I2 & 50 & 4.00 & 1.00 & 5.00 & 3.8800 & 0.89989 \\
I3 & 50 & 4.00 & 1.00 & 5.00 & 2.4200 & 1.07076 \\
I4 & 50 & 2.00 & 3.00 & 5.00 & 4.0600 & 0.68243 \\
I5 & 50 & 4.00 & 1.00 & 5.00 & 2.0800 & 1.22624 \\
I6 & 50 & 3.00 & 2.00 & 5.00 & 3.4400 & 0.57711 \\
I7 & 50 & 4.00 & 1.00 & 5.00 & 2.8800 & 1.22291 \\
I8 & 50 & 4.00 & 1.00 & 5.00 & 2.7400 & 1.15723 \\
\hline
\end{tabular}

Table 3. Results of power score analysis

\begin{tabular}{ccccccc}
\hline Power of SH & N & Range & Minimum & Maximum & Mean & $\begin{array}{c}\text { Std. } \\
\text { Deviation }\end{array}$ \\
\hline P1 & 50 & 4.00 & 1.00 & 5.00 & 3.9200 & 0.87691 \\
P2 & 50 & 4.00 & 1.00 & 5.00 & 3.2200 & 0.91003 \\
P3 & 50 & 4.00 & 1.00 & 5.00 & 3.1400 & 0.97813 \\
P4 & 50 & 2.00 & 3.00 & 5.00 & 4.0400 & 0.69869 \\
P5 & 50 & 4.00 & 1.00 & 5.00 & 2.0000 & 1.01015 \\
P6 & 50 & 4.00 & 1.00 & 5.00 & 3.1800 & 0.71969 \\
P7 & 50 & 4.00 & 1.00 & 5.00 & 3.0100 & 1.18511 \\
P8 & 50 & 4.00 & 1.00 & 5.00 & 3.1800 & 1.01035 \\
\hline
\end{tabular}

Stakeholders with High Interest and High Power - They are the most important stakeholder with high level of interest as well and high power, hence, they are referred to as "the key players" (Enserink et al., 2010) (Fig. 3). According to Table 1 and 2, the mean score of interest attribute is $4.1200(\mathrm{SD}=0.79898)$, the highest score; the value of power is 3.9200 (SD $=0.87691)$, the second place. The water company is the most important stakeholder because they directly treat water and deliver to users, and it controls water quality to ensure safe and adequate water supply. In addition, the water company benefit highly from the production and supply of clean water (Gialai Water Company, 2018).

With the mean scores of interest and power are $4.0600(\mathrm{SD}=0.68243)$ and $4.0400(\mathrm{SD}=$ 0.69869 ), the second highest scores are of governments. They enact policies and laws related to the water supply, so they are high power to create mechanisms, which helps operate water supply system, resulting in benefits from achievements of public health, social costs and tax obligations from water users and businesses.

There are three main components of the water supply system in Pleiku city, including Water Source (Bien Ho), two water supply plants (Saigon-Pleiku Plant, Bien Ho Water Plant) and pipeline network system (Anh et al., 2019). In which, the Department of Natural Resources and Environment will manage the water resource (Bien Ho), the Department of Construction will manage the pipeline network. This show why key agencies are the third place in mean score with mean value of Interest $=3.4400(\mathrm{SD}=$ $0.57711)$ and that of Power $=3.1800(\mathrm{SD}=$ $0.71969)$.

Stakeholder with High Interest but Low Power - These stakeholders need to be kept in loop by keeping them informed. They can prove to be powerful allies in influencing other powerful stakeholder (Chandraprabha, 2019). The fourth place of interest score is Users with mean $=3.8800(\mathrm{SD}=0.89989)$, the mean value of power is $3.2200(\mathrm{SD}=0.91003)$. User who are 
using water supplied from the system, they have great benefits from adequate and safe water. They have to pay for water service, and have the right to appeal when the water service does not meet the requirements.

Stakeholder with Low Interest but High Power - They are an important group of stakeholders because any change in their degree of interest has huge influence on the project at hand. Hence, they are "the context setters". They just need to be monitored. All that is required from such stakeholders is feedback, cooperation and some assistance when necessary (Xue, 2018). There are also media organizations involved in posting news, writing articles about issues related to the water supply system. Experts and professional organizations will be independent critics on issues, incidents and information related to system components, in some cases they should be consulted before making decisions and policies. In addition, they carry out studies to help clarify issues, planning and warnings such as water resources, water supply systems, water treatment processes, water safety plans, and others related to water issues. For media group, the mean scores of interest and power are 2.8800 $(\mathrm{SD}=1.22291)$ and $3.0100(\mathrm{SD}=1.18511)$, and for experts and institutions these figures are $2.7400(\mathrm{SD}=1.15723)$ and $3.1800(\mathrm{SD}=$
1.01035). The scores are quite similar for this group. These results are consistent with the study of (Wang et al., 2013)

In addition, there are a number of organizations and related agencies in the state agencies group such as the Preventive Medical Center that will check the quality of water in pipes and at user tap water, Environmental Police (detect, treat) penalties related to water, Gialai power company supplying electricity for operating plants, and Gialai Irrigation Joint Stock Company that manage Bien Ho B (there is a dam separating Ho A and Ho B of T'Nung Lake) (Anh et al., 2019). This group has the mean value of Interest $=2.4200(\mathrm{SD}=1.07076)$ and that of Power $=3.1400(\mathrm{SD}=0.97813)$.

Stakeholders with Low Interest and Low Power - They have a low level of interest and possess little power to have significant influence. Hence, they are referred to as "the crowd". The community in the study area is also related to the system with the level of being responsible for protecting water sources and network systems. This is expressed through the mean value of interest and power are $2.0800(\mathrm{SD}=1.22624)$ and2.0000 (SD = 1.01015).

\subsection{The level of involvement of each stake-} holder

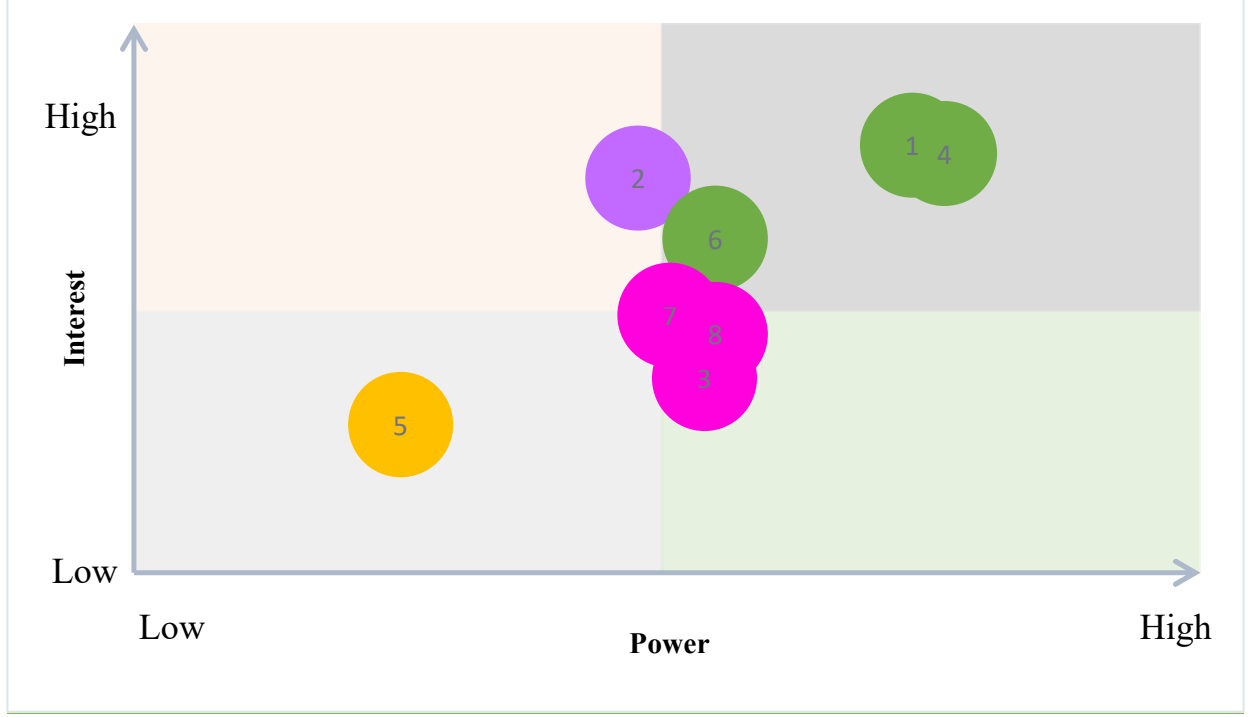

Fig. 3. Interest - Power Matrix 
After analyzing the mean scores for the stakeholders, the interest-power matrix shows the positions of the stakeholders. Gorvernment and water company are the highest in the levels of power and interest points and are an active participant in the management of water supply system. Users and Key agencies in positions that have more power and interest than the rest of stakeholders in managing and operating the water system. These four stakeholders Media and experts, institutions havesimilar positions of power and interest. Regardless of their high power, they are generally not the main target for engagement, but cannot be ignored (Grimble and Wellard, 1997). With limited power and little interest in the water supply system, there is little need to extensively engage with communities. State agencies are able to participate with a minimum, with little interest in the process. The number from 1 to 8 correspond to stakeholders (SH) from 1 to 8 in Table 4.

Table 4. The involvement levels of stakeholders

\begin{tabular}{cccll}
\hline SH & Interest & Power & Classification & Involvement \\
\hline 1 & 4.1200 & 3.9200 & Definitive & Co-working \\
2 & 3.0800 & 3.2200 & Definitive & Co-working \\
3 & 2.4200 & 3.1400 & Expectant & Co-thinking \\
4 & 4.0600 & 4.0400 & Definitive & Co-working \\
5 & 2.0800 & 2.0000 & Latent & Co-knowing \\
6 & 3.4400 & 3.1800 & Definitive & Co-working \\
7 & 2.8800 & 3.0100 & Expectant & Co-thinking \\
8 & 2.7400 & 3.1800 & Expectant & Co-thinking \\
\hline
\end{tabular}

Stakeholders who are active involvement are water company, governments, consumers, and key agencies. They are considered as co-working stakeholders. They should involve actively in the policy-making process. Expectant stakeholders (co-thinking) are experts and institutions, media,state agencies should be consulted in order to gain useful informations and opinions from various sources, which help improve the efficency of water supply system. The appropriate level of involvement for the latent stakeholders is co-knowing (Communities).

\section{Conclusions}

From the results of the analysis and grouping into the level of participation of stakeholders, when studying and issuing policies related to water supply systems, it is necessary to consider the appropriate level of participation of stakeholders. Making appropriate decisions, helping to operate the system well. At the same time, clearly defining responsibilities, obligations and powers for the parties to implement and coordinate the implementation is best done in reality. This helps ensure safe water delivery to users, the ultimate goal of the water supply system, which helps to ensure the health of the user community.

The review exercises power and benefits to consider the appropriate level of participation among stakeholders, from which there are solutions to adjust to improve the operation efficiency of the water supply system

\section{Acknowledgements}

Authors would like to acknowledge the finance support of Nong Lam University of Ho Chi Minh City - Gialai campus. Data are collected during a study of authors that are funded the university.

\section{References}

1. Aggens, L., Creighton, J.L., Dunning, C.M., 1995. Identifying different levels of public interest in participation, Public involvement techniques: a reader of ten years experience at the institute for water resources. IWR Research Report 82-R-1.

2. Anh, N.T., Hai, N.N.,Ky, N.M., 2019. Risk assessment and management in domestic water supply system in Pleiku city - Gialai province. Journal of Science and Technology, Danang University, 17 (6): 50-55.

3. Bartram, J., Davison, A., Howard, G., Stevens, M., Callan, P., Fewtrell, L., Deere, D., 2005. Water safety plans: Managing drinkingwater quality from catchment to consumer.WHO, Geneva. 
4. Bourne, L., Walker, D.H.T., 2005. Visualising and Mapping Stakeholder Influence. Management Decision, 43 (5): 649-660.

5. Caputo, A., 2013. Systemic Stakeholders' Management for Real Estate Development Projects. Global Business and Management Research, 5 (1): 66-82.

6. Chandraprabha, J.F.H., 2019. Urban water truck: sustainable urban logistics. Chalmers University of Technology, Göteborg, Sweden.

7. Conallin, J.C., Dickens, C., Hearne, D., Allan, C., 2017. Stakeholder Engagement in Environmental Water Management. Academic Press, USA.

8. Department for International Development (DFID), 2003. Tools for development: A handbook for those engaged indevelopment activity. London, United Kingdom.

9. Driscoll, C., Starik, M., 2004. The primordial stakeholder: Advancing the conceptual consideration of stakeholder status for the natural environment. Journal of Business Ethics, 49 (1): 55-73.

10. Enserink, B., Kwakkel, J., Bots, P., Hermans, L., Thissen, W., Koppenjan, J., 2010. Policy analysis of multi-actor systems. Eleven International Publishing.

11. Freeman, R.E., 1984. Strategic Management: A Stakeholder Approach. Cambridge University Press.

12. Gialai water company, 2018. Yearly financial report. Gialai.

13. Gibson, K., 2000. The Moral Basis of Stakholder Theory. Journal of Business Ethics, 26 (3): 245-257.

14. Grimble, R., Wellard, K., 1997. Stakeholder methodologies in natural resource management: A review of principles, contexts, experiences and opportunities. Agricultural Systems, 55 (2): 173-193.

15. Likert, R., 1932. A technique for the measurement of attitudes. Archives of Psychology, 140: 5-55.

16. Ministry of Natural Resources and Environment (MONRE), 2014. Vietnam state of En- vironmental reports. Hanoi.

17. Reed, M.S., Graves, A., Dandy, N., Posthumus, H., Hubacek, K., Morris, J., Prell, C., Quinn, C.H., Stringer, L.C., 2009. Who's in and why? A typology of stakeholder analysis methods for natural resource management. Journal of Environmental Management, 90 (5): 1933-1949.

18. Romanelli, A., Massone, H.E., Escalante, A.H., 2011. Stakeholder Analysis and SocialBiophysical Interdependencies for Common Pool Resource Management: La Brava Wetland (Argentina) as a Case Study. Environmental Management, 48 (3): 462-474.

19. Stanghellini, P.S.L., Collentine, D., 2008. Stakeholder discourse and water management implementation of the participatory model CATCH in a Northern Italian alpine sub-catchment. Hydrology and Earth System Sciences, 12 (1): 317-331.

20. Stanghellini, P.S.L., 2010. Stakeholder involvement in water management: The role of the stakeholder analysis within participatory processes. Water Policy, 12 (5): 675-694.

21. Suchman, M.C., 1995. Managing Legitimacy: Strategic and Institutional Approaches. The Academy of Management Review, 20 (3): 571-610.

22. Varvasovszky, Z., 2000. A stakeholder analysis. Health Policy and Planning, 15 (3), 338-345.

23. Wang, J., Ge, J., Lu, Q., 2013. Stakeholder involvement in the drinking water supply system: A case study of stakeholder analysis in China. Journal of Water Supply: Research and Technology-Aqua, 62 (8): 507-514.

24. World Health Organization (WHO), 2005. Water safety plan: Managing drinkingwater quality from catchment to consumer. WHO, Geneva.

25. World Health Organization (WHO) and International Water Association (IWA), 2009. Water safety plan manual: Step-by-step risk management for drinking-water suppliers. WHO, Geneva. 
26. World Health Organization (WHO), basin in South China. International Journal of 2011. Guidelines for drinking-water quality Water Resources Development, 34 (2): 166-191. $\left(4^{\text {th }} E d\right)$. WHO, Geneva.

29. Xue, L., 2018. For the balance of stake-

27. World Health Organization (WHO), holders'power and responsibility. Management 2014. Preventing diarrhoea through better Decision, 56 (3): 550-569.

30. Yawson, R.M., Greiman, B., 2014. Stakeimpacts in low and middle-income holder Analysis as a Tool for Systems Approach tries.WHO, Geneva Research in HRD. Proceedings of the 21 st An-

28. Yang, L.E., Chan, F.K.S., Scheffran, J., nual AHRD International Research Conference 2018. Climate change, water management and in the Americas. Texas, USA. stakeholder analysis in the Dongjiang River 